Vlachos, Hellas and Hellenism: a Social and Cultural History of Ancient Greece, Boston, 1936. Good sense and pleasant reading (A. D. Fraser). W. W. Ewbank, Poems of Cicero, London, 1933. Meets a decided want (Gertrude Hirst). Yale Classical Studies, volumes IV and V, ed. A. M. Harmon, 1934. Indica- tion of contents (M. Hadas). A. Maurizio, Histoire de lalimentation vegetale depuis la prehistoire jusqu'à nos jours, Paris, 1932. Useful, though inadequate for classical times (K. P. Vickery). Reviews of Kelsey and Meinecke, Third Year Latin, Boston, 1933, and other text-books.

\title{
CORRESPONDENCE
}

\section{To the Editors of the CLASSICAL REviEw.}

DEAR SiRS,

The space allowed for my review ${ }^{1}$ of Mr. Moore's translation of the Ars Amatoria was short. I tried to do the best service I could to a book well worth a second edition by adding some criticisms, mainly on points of detail, to a general commendation. Some of these criticisms are no doubt 'matters of opinion,' and I am sorry if the need for brevity betrayed me into the appearance of dogmatism. Mr. Moore and I must agree to differ about the proper scope of an Introduction meant for the general reader. I will add only that the differences between ancient civilization and our own should be emphasised no less than the similarities, and then confine myself to two points raised by his letter.

(i) At i, 429 he translates quasi natali ... poscit munera libo by 'she begs a trifle for her birthday cake'. He 'does not agree-nor does the Loeb translator-' that libo is ablative of

1 C.R. XLIX. 192. For Mr. Moore's reply see $C \cdot R$. L. 43 . means. But what then is the construction? Quite apart from questions of Latinity, surely a puella of the kind concerned could provide herself with the customary sacrificial cake? If any doubts remain, $A m$. $I$, viii, 93.4 should be decisive :

cum te deficient poscendi munera causae, natalem libo testificare tuum.

P. Brandt on A.A. i, 429 would have given Mr. Moore some guidance, though the parallel from the Amores is not there cited.

(ii) At ii, 735-38 I criticized Mr. Moore for a 'violent departure from the Latin order' and drew from him a protest which seems to repeat the words directed by R. J. Cholmeley at Wilamowitz (Theocritus, and ed., p. 249). It is true that the six proper names are troublesome. But I have seen the verses rendered with less dislocation, and I believe that $\mathrm{Mr}$. Moore himself, on second thoughts, could do better. One can prefer a closer version (which reads as well) without being pedantic.

Very truly yours,

T. F. HighaM.

23 April 1936.

\section{BOOKS RECEIVED}

All publications which have a bearing on classical studies will be entered in this list if they are sent for review. The price should in all cases be stated.

* Excerpts or extracts from periodicals and collections will not be included unless they are also published separately.

Allan (D. J.) Aristotelis de Caelo libri IV. Recognovit brevique adnotatione critica instruxit D. J. A. (Scr. Class. Bibl. Oxon.) Oxford: Clarendon Press, 1936. Cloth, 7s. 6d.

Anderson (W. B.) Sidonius. Poems and Letters. With an English translation, introduction, and notes. In two volumes. I. Poems; Letters, Books I.II. Pp. lxxv+ 483. (Loeb Classical Library.) London: Heinemann, 1936. Cloth, Ios. (leather, I2s. 6d.).

Apophoreta Gotoburgensia Vilelmo Lundström oblata. Pp. viii + 447. Göteborg : Elanders Boktryckeri, 1936, Paper, 15 kr.

Babbitt (F. C.) Plutarch's Moralia, with an English translation. IV. 263D-35IB. Pp. xiv+553. V. 35IC-438E. Pp. xii +5I5. (Loeb Classical Library.) London: Heine- mann, 1936. Cloth, 10s. (leather, 12s. 6d.) each.

Baynes (N. H.) The Political Ideas of St. Augustine's De Civitate Dei. Pp. 18. (Historical Association Pamphlet, No. 104.) London: G. Bell, 1936. Paper, Is.

Bethe (E.) Ahnenbild und Familiengeschichte bei Römern und Griechen. Pp. xiii + I2I ; 4 plates. Munich : Beck, 1935. (Export prices) cloth, RM. 2.85 ; unbound, 2.10.

Blum (C.) Studies in the dream-book of Artemidorus. Pp. 108. Uppsala : Almqvist och Wiksell, 1936. Paper.

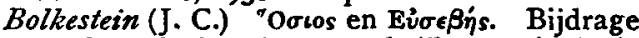
tot de godsdienstige en zedelijke terminologie van de Grieken. Avec un résumé en français. Pp. 225+iv. Amsterdam: H. J. Paris, 1936. Paper.

Borzsak (S.) Die Kenntnisse des Altertums 